\title{
EVALUASI KEMAMPUAN GURU DALAM MENGIMPLEMENTASI PEMBELAJARAN TEMATIK DI SD KECAMATAN SALAHUTU KABUPATEN MALUKU TENGAH
}

\section{AN EVALUATION OF ABILITY OF THE TEACHER IN IMPLEMENTATION OF THEMATIC TEACHING IN ELEMENTARY SCHOOLS IN SALAHUTU DISTRICT, CENTRAL MALUKU}

\author{
Nurmin, Badrun Kartowagiran \\ MAN 2 Ambon, Universitas Negeri Yogyakarta \\ kondowan@yahoo.com, badrunkw@yahoo.com
}

\begin{abstract}
Abstrak
Evaluasi ini bertujuan untuk mengungkapkan kemampuan guru dalam mengimplementasi pembelajaran tematik di sekolah dasar (SD) di Kecamatan Salahutu, Kabupaten Maluku Tengah yang terkait dengan kemampuan guru dalam perencanaan pembelajaran tematik, pelaksanaan pembelajaran tematik, dan penilaian pembelajaran tematik. Evaluasi yang dilakukan terhadap kemampuan guru dalam mengimplementasi pembelajaran tematik menggunakan metode deskriptif dan pendekatan kuantitatif serta menggunakan model evaluasi Stake's Countenance Model. Hasil evaluasi menunjukan: (1) Sebagian besar (91,2\%) guru SD di Kecamatan Salahutu, Kabupaten Maluku Tengah menyatakan perencanaan pembelajaran tematik dengan kategori cukup baik. (2) Sebagian besar (76,5\%) guru SD di Kecamatan Salahutu, Kabupaten Maluku Tengah melaksanakan proses pembelajaran tematik dengan kategori cukup baik. (3) Sebagian besar (91,2\%) guru SD di Kecamatan Salahutu, Kabupaten Maluku Tengah mampu melaksanakan penilaian pembelajaran tematik dengan kategori cukup baik.
\end{abstract}

Kata kunci: evaluasi program, pembelajaran tematik.

\begin{abstract}
This evaluation aims to determine the ability of the teachers in implementation of thematic teaching in elementary schools in Salahutu District, Central Maluku related to the ability of the teachers in in preparing the thematic teaching plan, the implementation of thematic teaching, and the implementation of thematic teaching assessment. The evaluation of the ability of the teachers in implementation of thematic teaching using descriptive method with quantitative approach and using evaluation Stake's Countenance Model. The results are as follows: (1)Most (91.2\%) elementary school teachers in District Salahutu, Central Maluku are said that the ability of the teachers in implementation of thematic teaching in a good enough category. (2) Most (76.5\%) of the elementary school teachers in Salahutu District, Central Maluku are implement the thematic taching process with good enough category. (3) Most (91.2\%) elementary school teachers in Salahutu District, Central Maluku are are able to carry out the assessment of thematic teaching with a good enough category.
\end{abstract}

Keywords: evaluation programme, thematic teaching. 


\section{Pendahuluan}

Pendidikan di Indonesia diselenggarakan bertujuan untuk mengembangkan kemampuan dan membentuk watak serta peradaban bangsa yang bermartabat dalam rangka mencerdaskan kehidupan bangsa. Seiring dengan tujuan yang ingin dicapai, pemerintah mengeluarkan regulasi sebagaimana yang tercantum dalam permendiknas No 22 Tahun 2006 tentang Standar Isi. Kebijakan ini antara lain memberi ruang gerak yang luas kepada lembaga pendidikan khususnya sekolah dasar dalam mengelola sumber daya yang ada, dengan cara mengalokasikan seluruh potensi dan prioritas sehingga mampu melakukan terobosan-terobosan sistem pembelajaran yang lebih inovatif kreatif, dan konstruksif, dan berwawasan luas. salah satunya adalah dengan menggunakan model pembelajaran tematik.

Strategi pembelajaran dengan menggunakan pendekatan tematik atau pembelajaran tematik sebenarnya telah diisyaratkan sejak kurikulum 1994. Namun angka mengulang kelas dan angka putus sekolah peserta didik kelas satu SD jauh lebih tinggi dibandingkan dengan kelas yang lain. Data tahun 1999/2000 memperlihatkan bahwa angka mengulang kelas satu sebesar 11,6\% sementara pada kelas dua 7,51\%, kelas tiga $6,13 \%$, kelas empat 4,64\%, kelas lima $3,1 \%$, dan kelas enam 0,37\%. (Trianto, 2009, p.11).

Secara empiris, berdasarkan hasil analisis penelitian terhadap rendahnya hasil belajar peserta didik tersebut disebabkan dominannya proses pembelajaran secara konvensional. Pada pembelajaran ini suasana kelas cenderung teacher-centered sehingga siswa cenderung pasif. Dalam hal ini siswa tidak diajarkan strategi belajar yang dapat memahami bagaimana belajar, berpikir, dan memotivasi diri sendiri (self motivation), padahal aspek tersebut merupakan kunci keberhasilan dalam pembelajaran (Trianto, 2010, p.5). Akhirnya, proses pembelajaran yang terjadi hanya sebatas pada penyampaian informasi saja (transfer of knowledge), kurang terkait dengan lingkungan sehingga siswa tidak mampu memanfaatkan konsep kunci keilmuan dalam proses pemecahan masalah kehidupan yang dialami siswa sehari-hari.

Pemasalahan-permasalahan intern tersebut juga dialami di Kabupaten Maluku Tengah, sebagaimana hasil wawancara dengan salah satu guru SD di Kecamatan Salahutu yang menyatakan bahwa pelaksanaan pembelajaran tematik di Kecamatan Salahutu belum menyelesaikan masalah kemampuan dasar siswa terutama kemampuan membaca, menulis maupun menghitung walaupun sudah di kelas 3 SD. Hal ini disebabkan oleh keterbatasan kemampuan guru dalam merencanakan dan melaksanakan pembelajaran tematik serta penilaian pembelajaran tematik. Baik yang disebabkan oleh proses pendidikan yang dilaluinya maupun kurangnya pelatihan tentang pembelajaran tematik mengakibatkan pembelajaran dengan menggunakan pendekatan tematik tidak dapat diwujudkan dengan baik. Terlebih lagi disadari, bahwa penerapan pembelajaran dengan menggunakan pendekatan ini memerlukan persiapan yang tinggi dari guru, dalam hal waktu, sumber, bahan ajar, serta perangkat pendukung lainnya. Oleh karena itu penelitian tentang evaluasi kemampuan guru dalam mengimplementasi pembelajaran tematik di kelas rendah sekolah dasar sangat diperlukan.

Tujuan evaluasi ini adalah untuk memberikan gambaran kemampuan guru dalam perencanaan pembelajaran tematik, pelaksanaan pembelajaran tematik, dan penilaian pembelajaran tematik di Kabupaten Maluku Tengah Provinsi Maluku.

Manfaat evaluasi ini adalah untuk memberikan gambaran yang jelas tentang pelaksanaan pembelajaran tematik, memberikan penyajian (bukti empirik) tentang pelaksanaan pembelajaran tematik, dan sebagai referensi bagi praktisi pendidikan dalam mengembangkan pembelajaran tematik di sekolah dasar Kecamatan Salahutu Kabupaten Maluku Tengah pada kelas rendah.

Teori yang melandasi pembelajaran tematik adalah teori Gestalt. Menurut Gestalt "Belajar adalah proses pengembangan insight. Insight adalah pemahaman terhadap hubungan antarbagian di dalam suatu situasi permasalahan". Lebih lanjut gestalt menjelaskan insight adalah inti dari pembentukan tingkah laku. Teori ini memandang bahwa belajar adalah proses insight atau pemahaman baru atau mengubah pemahaman lama. Pemahaman terjadi apabila individu menemukan cara baru dalam menggunakan unsur-unsur yang ada dalam lingkungan, termasuk struktur tubuhnya sendiri. Gelstalt melihat bahwa belajar merupakan perbuatan yang bertujuan, ekspolaratif, imajinatif, dan kreatif. Pemahaman atau insight merupakan citra dari atau perasaan tentang pola-pola atau hubungan (Wina, 2011, p.120). 
Selain itu dalam pembelajaran tematik di sekolah dasar juga memiliki landasan filosofis, landasan psikologi, dan landasan yuridis. Secara Filosofis pembelajaran tematik berlandaskan pada filsafat pendidikan progresivisme, kontruktivisme dan humanisme. Aliran progresivisme memandang proses pembelajaran perlu ditekankan pada pembentukan kreativitas, pemberian sejumlah kegiatan siswa, suasana yang alami (natural), dan memperhatikan pengalaman siswa. Aliran konstruktivisme melihat pengalaman langsung siswa (direct experiences) sebagai kunci dalam pembelajaran, dalam hal ini isi atau materi pembelajaran perlu dihubungkan dengan pengalaman siswa secara langsung. Menurut aliran ini pengetahuan adalah hasil konstruksi atau bentukan manusia. Manusia mengkonstruksi pengetahuannya melalui interaksi dengan objek, fenomena, pengalaman dan lingkungannya. Pengetahuan tidak dapat ditransfer begitu saja dari seorang guru kepada siswa, tetapi harus diinterpretasikan sendiri oleh masing-masing siswa. Aliran humanisme melihat siswa dari segi keunikan/kekhasannya, potensinya, dan motivasi yang dimilikinya. Siswa selain memiliki kesamaan juga memiliki kekhasan. Implikasi dari hal tersebut dalam kegiatan pembelajaran yaitu: (1) layanan pembelajaran selain bersifat klasikal, juga bersifat indivudual; (2) pengakuan adanya siswa yang lambat (slow learner) dan siswa yang cepat; (3) penyikapan terhadap hal-hal yang unik dari diri siswa, baik yang menyangkut faktor personal/individual maupun yang menyangkut faktor lingkungan sosial/kemasyarakatan (Hermawan, 2007, p.4)

Landasan psikologis terutama berkaitan dengan psikologi perkembangan peserta didik dan psikologi belajar. Psikologi perkembangan peserta didik diperlukan terutama dalam menentukan isi/materi pembelajaran tematik yang diberikan kepada siswa agar tingkat keluasan dan kedalamannya sesuai dengan tahap perkembangan peserta didik. Psikologi belajar memberikan kontribusi dalam hal bagaimana isi/materi pelajaran tematik tersebut disampaikan kepada siswa dan bagaimana pula siswa harus mempelajarinya. Melalui pembelajaran tematik diharapkan adanya perubahan perilaku siswa menuju kedewasaan baik fisik, mental/intelektual, moral maupun sosial.

Landasan yuridis berkaitan dengan berbagai kebijakan atau peraturan yang mendukung pelaksanaan pembelajaran tematik di sekolah dasar. Dalam UU No 23 tahun 2002 pasal 9 tentang perlindungan anak, dinyatakan bahwa setiap anak berhak memperoleh pendidikan dan pengajaran dalam rangka pengembangan pribadinya dan tingkat kecerdasan sesuai dengan minat dan bakatnya. Dalam UU No 20 Tahun 2003 tentang Sistem Pendidikan Nasional dinyatakan bahwa setiap peserta didik pada setiap satuan pendidikan berhak mendapatkan pelayanan pendidikan sesuai dengan bakat, minat dan kemampuannya (Bab V Pasal 1.b).

Pembelajaran tematik merupakan pembelajaran yang pengembangannya dimulai dengan menentukan topik tertentu sebagai tema atau topik sentral, setelah tema ditetapkan maka selanjutnya tema itu dijadikan dasar untuk menentukan dasar sub-sub tema dari bidang studi lain yang terkait (Fogarty, 1991, p.54).

Dixon dan Collins (1991, p.7) mengatakan bahwa pembelajaran tematik adalah suatu pembelajaran yang melibatkan beberapa bidang studi untuk memberikan pengalaman yang bermakna kepada siswa dengan mengaitkan sebuah tema. Siswa memahami konsep-konsep yang mereka pelajari itu melalui pengalaman langsung serta menghubungkannya dengan konsep lain yang sudah mereka pahami. Pembelajaran tematik lebih melibatkan siswa aktif secara mental dan fisik di dalam kegiatan belajar mengajar di kelas.

Loughran (2005, p.113) mendefinisikan pembelajaran tematik bahwa:

Thematic teaching can be defined as the process of integrating and linking multiple elements of a curriculum in an ongoing exploration of many different aspects of a topic or subject. It involves a constant interaction between teacher and students and their classroom environment. Among the important elements that foster success in any thematic project are initiation of the theme, the teacher's role group exploration, integration of the theme with the curriculum and learning centers, and building and maintaining spirit and enthusiasm.

Pembelajaran tematik didefinisikan sebagai proses integrasi dan menghubungkan beberapa elemen kegiatan kurikulum dari berbagai aspek dan topik atau subjek. Interaksi ini melibatkan antara guru, siswa dan lingkungan kelas. Unsur-unsur penting dalam pembelajaran tematik adalah tema, eksplorasi guru, integrasi tema dengan kurikulum dan pusat belajar, serta membangun atau menjaga semangat dan antusiasme siswa. 
Pembelajaran tematik pada dasarnya adalah model pembelajaran terpadu yang menggunakan tema untuk mengaitkan beberapa pelajaran sehingga dapat memberikan pengalaman bermakna kepada siswa (Depdiknas, dalam Triyanto, 2011. p.147). Dalam pelaksanaannya, pendekatan pembelajaran tematik ini bertolak dari suatu tema yang dipilih dan dikembangkan oleh guru bersama peserta didik dengan memperhatikan keterkaitannya dengan isi mata pelajaran. Tema dalam pembelajaran tematik menjadi sentral yang harus dikembangkan. Penggabungan beberapa kompetensi dasar, indikator serta isi mata pelajaran dalam pembelajaran tematik akan terjadi penghematan karena tumpang tindih materi dapat dikurangi bahkan dihilangkan. Siswa mampu melihat hubunganhubungan yang bermakna, sebab isi/materi pembelajaran lebih berperan sebagai sarana atau alat, bukan merupakan tujuan akhir. Pembelajaran menjadi utuh sehingga siswa akan mendapat pengertian mengenai proses dan materi pelajaran secara utuh pula. Dengan adanya pemaduan antarmata pelajaran maka penguasaan konsep akan semakin baik dan meningkat.

BSNP (2006, p.35) menetapkan pendekatan tematik dalam pembelajaran di SD dikarenakan perkembangan peserta didik pada kelas rendah sekolah dasar, pada umumnya berada pada tingkat perkembangan yang masih melihat segala sesuatu sebagai satu keutuhan (holistik) serta baru mampu memahami hubungan antara konsep secara sederhana. Oleh karena itu proses pembelajaran masih bergantung kepada objek konkret dan pengalaman yang dialami secara langsung. Pembelajaran yang dilakukan dengan mata pelajaran terpisah menyebabkan kurang mengembangkan anak untuk berpikir holistik dan membuat kesulitan bagi peserta didik mengaitkan konsep dengan kehidupan nyata mereka sehari-hari. Akibatnya, para siswa tidak mengerti manfaat dari materi yang dipelajarinya untuk kehidupan nyata. Sistem pendidikan seperti ini membuat manusia berpikir secara parsial, terkotak-kotak. Penetapan pendekatan tematik dalam proses pembelajaran juga diharapkan dapat menjembatani pendidikan yang telah dialami anak di Taman Kanak-kanak (TK), sehingga dapat menekan angka mengulang kelas yang masih tinggi terutama pada kelas rendah.

Dalam jurnal yang berjudul Thematic Teaching in Action (Loughran, 2005) mengatakan bahwa dalam ruang kelas pembelajaran tematik sukses jika pembelajaran dikerahkan pada tangan dan pikiran siswa. Pembelajaran tematik sebagai proses mengintegrasikan dan menghubungkan beberapa unsur dari kurikulum dalam eksplorasi berkelanjutan dari berbagai aspek dari topik atau subjek, dan menyajikan beberapa contoh dari kurikulum. Hal ini menyiratkan bahwa dalam pembelajaran tematik harus melibatkan interaksi secara terusmenerus antara guru, siswa dan lingkungan belajar. Unsur-unsur penting yang mendorong keberhasilan dalam setiap pembelajaran tematik merupakan inisiasi dari tema, peran guru, eksplorasi kelompok, integrasi tema dengan kurikulum dan pusat-pusat pembelajaran, dan membangun dan memelihara semangat dan antusiasme. Sehingga jika proses pembelajaran tematik dilaksanakan sesuai dengan konsep model pembelajaran tematik maka pembelajaran lebih bermakna bagi siswa dan dapat meningkatkan prestasi belajar siswa di kelas.

Pembelajaran tematik lebih menekankan pada penerapan konsep belajar sambil melakukan sesuatu (learning by doing). Oleh karena itu, guru perlu mengemas atau merancang pengalaman belajar yang mempengaruhi kebermaknaan belajar siswa. Pengalaman belajar yang menunjukkan kaitan unsur-unsur konseptual menjadikan proses pembelajaran lebih efektif. Kaitan konseptual antarmata pelajaran yang dipelajari akan membentuk skema, sehingga siswa akan memperoleh keutuhan dan kebulatan pengetahuan. Selain itu, dengan penerapan pembelajaran tematik di sekolah dasar sangat membantu siswa, karena sesuai dengan tahap perkembangannya siswa yang masih melihat segala sesuatu sebagai satu keutuhan (holistik).

Hudson (2009, p.20) mengatakan bahwa "... Effective classrooms are all about learning, they are not about teaching and the teacher who focuses on him/herself has the wrong focus". Efektifitas kelas adalah semua tentang belajar, bukan tentang pengajaran dan guru yang fokus pada dia/dirinya sendiri adalah fokus yang salah. Artinya, proses interaksi antara guru dan siswa adalah sangat penting, tidak memfokuskan pada satu arah yang mengakibatkan transfer and receive, guru memberi materi dan siswa hanya menerima pengetahuan yang disampaikan guru. Di sini siswa dituntut untuk aktif dan kritis terhadap pengetahuan bidang studi tertentu, sedangkan guru berfungai sebagai fasilitator.

Kualitas pendidikan juga dapat diukur dari tercapainya proses pembelajaran di mana kaitannya dengan standar proses yang tercantum pada Peraturan Pemerintah tentang Stan- 
dar Nasional pendidikan. Komponen yang ada dalam standar proses pendidikan yakni perencanaan pembelajaran, pelaksanaan pembelajaran, penilaian hasil pembelajaran, dan pengawasan pembelajaran.

Martin, et al (2005,p.112) mengatakan bahwa perencanaan pembelajaran yang dibuat harus melibatkan siswa dalam berbagai kegiatan inkuiri dan penemuan pengetahuan dasar serta kemampuan memecahkan masalah. Perencanaan pembelajaran terkait dengan dua hal yakni silabus dan RPP, di mana silabus sebagai acuan pengembangan RPP yang memuat identitas mata pelajaran atau tema pelajaran, standar kompetensi, kompetensi dasar, materi pembelajaran, kegiatan pembelajaran, indikator pencapaian kompetensi, penilaian, alokasi waktu, dan sumber belajar. Sedangkan RPP dijabarkan dari silabus untuk mengarahkan kegiatan belajar siswa dalam upaya mencapai kompetensi dasar.

Chiappetta \& Koballa (2010, p.72) mengatakan bahwa kemampuan melaksanakan pembelajaran merupakan kegiatan yang dilakukan guru untuk memimpin pelajaran dan mengimplementasikan tujuan pembelajaran. Hal-hal yang harus diperhatikan dalam proses pembelajaran yakni terpenuhinya syarat pelaksanaan pembelajaran, beban mengajar guru, adanya bu$\mathrm{ku}$ teks pelajaran. Pelaksanaan pembelajaran harus mempertimbangkan prinsip pembelajaran yakni memperhatikan perbedaan siswa secara individu, mendorong partisipasi aktif siswa, memberikan umpan balik dan tindak lanjut untuk mengetahui kemampuan siswa, serta pengelolaan kelas yang baik.

Penilaian hasil belajar dilakukan untuk mengukur tingkat pencapaian kompetensi siswa dan digunakan sebagai bahan penyusunan laporan kemampuan hasil belajar serta perbaikan proses pembelajaran. Sedangkan pengawasan dilakukan dengan memantau perencanaan, pelaksanaan, dan penilaian hasil belajar yang dilakukan oleh kepala sekolah dan pengawas satuan pendidikan.

Permasalahan dalam penelitian ini adalah bagaimanakah kemampuan guru sekolah dasar di Kecamatan Salahutu Kabupaten Maluku Tengah dalam perencanaan pembelajaran tematik, pelaksanaan pembelajaran tematik, dan penilaian pembelajaran tematik.

\section{Metode}

Jenis penelitian ini berupa penelitian evaluasi (evaluative research) yang bertujuan untuk memperoleh informasi yang akurat dalam mendeskripsikan keterlaksanaan pembelajaran tematik yang diselenggarakan di sekolah dasar pada kelas rendah. Pendekatan evaluasi yang digunakan dalam penelitian ini yaitu evaluasi model Stake (Stake's Countenance Model) yang membandingkan antara proses pembelajaran yang terjadi dilapangan dengan proses pembelajaran seharusnya sebagai kriteria untuk menentukan keberhasilan. Hasil evaluasi diharapkan dapat dijadikan sebagai dasar atau landasan untuk membuat rekomendasi dalam mendukung kebijakan atau keputusan tentang pembelajaran tematik.

Penelitian ini dilaksanakan di sekolah dasar se-Kecamatan Salahutu Kabupaten Maluku Tengah. Pengambilan data penelitian ini dilaksanakan pada bulan Februari 2013 sampai April 2013.

Populasi dalam penelitian ini adalah seluruh guru sekolah dasar di Kecamatan Salahutu Kabupaten Maluku Tengah. Teknik pengambilan sampel dilakukan dengan teknik purposive. Sampel dalam penelitian ini adalah guru sekolah dasar yang mengajar di kelas tiga seKecamatan Salahutu Kabupaten Maluku Tengah tahun ajaran 2012/2013.

Pengumpulan data dalam penelitian ini dilakukan dengan menggunakan angket, observasi dan dokumentasi. Sebelum pengambilan data di lapangan, instrumen berupa angket yang digunakan divalidasi terlebih dahulu oleh ahli. Setelah itu, uji coba yang dilakukan adalah uji coba terpakai yakni pengambilan data langsung ke lapangan dan data yang diperoleh diuji validitasnya menggunakan analisis faktor.

Uji coba yang dilakukan adalah pada instrumen perencanaan pembelajaran tematik, pelaksanaan pembelajaran tematik, dan penilaian pembelajaran tematik yang mengukur ketercapaian pelaksanaan proses pembelajaran dengan respon guru. Hasil dari uji KMO dan Bartlett's untuk instrumen guru dengan kriteria penerimaan yang digunakan yakni angka KMO Measure of Sampling Adequasi dan Barlett's Test lebih besar dari $0,5(>0,5)$ dan probabilitas di bawah $0,05(<0,05)$, maka butir tersebut dapat dianalisis lebih lanjut. 
Tabel 1. Uji KMO and Bartlett's Instrumen Kemampuan Guru dalam Implementasi Pembelajaran Tematik

\begin{tabular}{llrrr}
\hline \multicolumn{1}{c}{ Aspek } & $\begin{array}{c}\text { Perencanaan } \\
\text { Pembelajaran }\end{array}$ & $\begin{array}{r}\text { Pelaksanaan } \\
\text { Pembelajaran }\end{array}$ & $\begin{array}{c}\text { Penilaian } \\
\text { Pembelajaran }\end{array}$ \\
\hline Kaiser-Meyer-Olkin Measure of Sampling Adequacy. & 0,663 & 0,789 & 0,802 \\
Bartlett's Test of Sphericity & Approx. Chi-Square & 984,046 & 313,497 & 160.616 \\
& df & 325 & 36 & 21 \\
& Sig. & 0,000 & 0,000 & 0,000 \\
\hline
\end{tabular}

Berdasarkan Tabel 1 di atas, nilai KMO-MSA Instrumen Perencanaan Pembelajaran Tematik rata-rata lebih besar dari $0,5(\geq$ $0,5)$ termasuk kategori baik sehingga dapat dianalisis lebih lanjut menggunakan analisis faktor. Nilai signifikansi uji Bartlett's $0,000<$ 0,05 yang menunjukkan bahwa variabel-variabel tersebut saling berkorelasi menunjukkan bahwa analisis faktor dapat dilanjutkan.

Reliabilitas juga dilakukan pada instrumen dengan responden guru. Nilai koefisien reliabilitas yang digunakan adalah $\geq 0,65$ yang mengacu pada pendapat Cohen \& Swerdlik (2005, p.141) yang mengatakan bahwa koefisien reliabilitas 0,65 masih dianggap layak digunakan meskipun ada pada batas terendah di daerah penolakan.

Hasil analisis reliabilitas instrumen guru dapat dilihat pada Tabel 2. Nilai koefisien alpha pada analisis instrumen guru lebih besar dari 0,7 .

Tabel 2. Rangkuman Koefisien Reliabilitas Instrumen Angket

\begin{tabular}{|c|c|c|c|}
\hline No & Aspek yang Dinilai & $\begin{array}{l}\text { Koefisien } \\
\text { Alpha }\end{array}$ & Kesimpul \\
\hline 1 & $\begin{array}{l}\text { Kemampuan guru } \\
\text { dalam perencanaan } \\
\text { pembelajaran tematik }\end{array}$ & 0,961 & Reliabel \\
\hline 2 & Pelaksanaan proses & 0,948 & Reliabel \\
\hline 3 & Penilaian pembelajaran & 0,904 & Reliabel \\
\hline
\end{tabular}

\section{Hasil Penelitian dan Pembahasan}

Evaluasi ini dilakukan pada tiga puluh empat sekolah dasar di Kecamatan Salahutu Kabupaten Maluku Tengah. Hasil analisi statistik deskriptif kuantitatif berisi tentang kemampuan guru dalam: (1) perencanaan perangkat pembelajaran tematik, (2) pelaksanaan pembelajaran tematik, dan (3) penilaian pembelajaran tematik. Kriteria yang digunakan dalam evaluasi yakni berdasarkan standar interpretasi skor responden, apabila guru yang telah mengimplementasikan pembelajaran sesuai dengan konsep pembelajaran tematik berada pada interval: Angka 0\%-20\% = Tidak Baik, Angka 21\%-
$40 \%=$ Kurang Baik, Angka 41\%-60\% = Cukup Baik, Angka 61\%-80\% = Baik, dan Angka $81 \%-100 \%=$ Sangat Baik

\section{Perencanaan Pembelajaran Tematik}

Kemampuan guru dalam merencanakan pembelajaran tematik sebelum melakukan pembelajaran di kelas berada pada kriteria cukup baik. Hal ini didasarkan pada kemampuan guru dalam perencanaan program pembelajaran dan Pemetaan SK, KD dan Indikator masih berada pada kriteria cukup baik, sedangkan pembuatan jaringan tema, Pengembangan silabus, dan pengembangan rencana pelaksanaan pembelajaran (RPP) sudah termasuk dalam kriteria baik. Distribusi frekuensi perolehan skor perencanaan program pembelajaran tematik dapat dilihat pada Tabel 3 berikut.

Tabel 3. Distribusi Frekuensi Perolehan Skor Perencanaan Pembelajaran Tematik

\begin{tabular}{ccccc}
\hline No & Interval & Kategori & Frek & $\begin{array}{c}\text { Frekuensi } \\
\text { Relatif } \\
(\%)\end{array}$ \\
\hline 1 & $X<70$ & Kurang Sesuai & 0 & 0 \\
2 & $100>X \geq 70$ & Cukup Sesuai & 3 & 8,9 \\
3 & $130>X \geq 100$ & Sesuai & 13 & 38,2 \\
4 & $X \geq 130$ & Sangat Sesuai & 18 & 52,9 \\
\hline
\end{tabular}

Berdasarkan Tabel 3 dapat diketahui bahwa sebesar 52,9\% guru-guru SD di Kecamatan Salahutu Kabupaten Maluku Tengah dalam menyatakan perencanaan pembelajaran tematik termasuk kategori sangat sesuai, 38,2\% mengatakan dalam kategori sesuai, 8,9\% dalam kategori cukup sesuai dan pada kategori yang kurang sesuai tidak ada atau 0\%. Hal ini menunjukan bahwa rata-rata guru di SD Kecamatan Salahutu Kabupaten Maluku Tengah menyiapkan perangkat pembelajaran tematik dalam kategori cukup baik yang ditunjukkan oleh persentase terbesar pada frekuensi perolehan skor yang sangat sesuai berada pada interval angka 41\%-60\%. Aspek perencanaan pembelajaran tematik yang dibuat oleh guru meliputi (1) perencanaan program pembelajaran, (2) pemetaan SK, KD dan Indikator, (3) membuat jaring- 
an tema, (4) penyusunan silabus dan (5) pengembangan RPP.

\section{Perencanaan Program Pembelajaran}

Perencanaan program pembelajaran merupakan gambaran kesiapan dan persiapan yang perlu dibuat dan dilakukan oleh seorang guru. Distribusi frekuensi perolehan skor perencanaan program pembelajaran tematik dapat dilihat pada Tabel 4 berikut.

Tabel 4. Distribusi Frekuensi Perolehan Skor Perencanaan Program Pembelajaran

\begin{tabular}{ccccc}
\hline No & Interval & Kategori & Frek & $\begin{array}{c}\text { Frekuensi } \\
\text { Relatif (\%) }\end{array}$ \\
\hline 1. & $\mathrm{X}<14$ & Kurang Sesuai & 0 & 0 \\
2. & $20>\mathrm{X} \geq 14$ & Cukup Sesuai & 1 & 2.9 \\
3. & $26>\mathrm{X} \geq 20$ & Sesuai & 14 & 41.2 \\
4. & $\mathrm{X} \geq 26$ & Sangat Sesuai & 19 & 55.9 \\
\hline
\end{tabular}

Berdasarkan Tabel 4 dapat dijelaskan bahwa 55,9\% guru SD di Kecamatan Salahutu Kabupaten Maluku Tengah menyatakan pembuatan perencanaan program pembelajaran tematik termasuk dalam kategori sangat sesuai, $41,2 \%$ termasuk dalam kategori sesuai, 2,9\% termasuk dalam kategori cukup sesuai, dan tidak ada dalam kategori yang kurang sesuai. Hal ini menunjukan bahwa guru SD di Kecamatan Salahutu Kabupaten Maluku Tengah dalam membuat perencanaan program pembelajaran tematik yang meliputi penentuan tujuan pembelajaran, pembuatan perangkat pembelajaran, dan pembuatan kalender pendidikan termasuk dalam kategori cukup baik yang ditunjukkan oleh persentase terbesar pada frekuensi perolehan skor sangat sesuai berada pada interval angka $41 \%-60 \%$.

\section{Pemetaan SK, KD dan Indikator}

Pemetaan tema dilakukan untuk memperoleh gambaran secara menyeluruh dan utuh semua standar kompetensi, kompetensi dasar, dan indikator dari berbagai mata pelajaran yang dipadukan dalam tema yang dipilih. Distribusi frekuensi perolehan skor pemetaan SK, KD dan indikator pembelajaran tematik dapat dilihat pada Tabel 5 berikut.

Tabel 5. Distribusi Frekuensi Perolehan Skor Pemetaan SK, KD dan Indikator

\begin{tabular}{ccccc}
\hline No & Interval & Kategori & Frek & $\begin{array}{c}\text { Frekuensi } \\
\text { Relatif } \\
(\%)\end{array}$ \\
\hline 1 & $X<10,5$ & Kurang Sesuai & 0 & 0 \\
2 & $15>X \geq 10,5$ & Cukup Sesuai & 9 & 26,5 \\
3 & $19,5>X \geq 15$ & Sesuai & 8 & 23,5 \\
4 & $X \geq 19,5$ & Sangat Sesuai & 17 & 50,0 \\
\hline
\end{tabular}

Berdasarkan Tabel 5 dapat dijelaskan bahwa 50\% guru SD di Kecamatan Salahutu Kabupaten Maluku Tengah menyatakan melakukan pemetaan SK, KD dan indikator dalam pembelajaran tematik termasuk dalam kategori sangat sesuai, 23,5\% termasuk dalam kategori sesuai, 26\% termasuk dalam kategori cukup sesuai, dan tidak ada dalam kategori kurang sesuai. Hal ini menunjukan bahwa guru SD di Kecamatan Salahutu Kabupaten Maluku Tengah dalam melakukan pemetaan SK, KD dan indikator pembelajaran tematik yang meliputi indikator penjabaran SK, KD, dan indikator, penentuan tema, dan identifikasi dan analisis SK, KD, dan indikator dalam kategori cukup baik yang ditunjukkan oleh persentase terbesar pada frekuensi perolehan skor sangat sesuai berada pada interval angka $41 \%-60 \%$.

\section{Pembuatan Jaringan Tema}

Pembuatan jaringan tema merupakan pola hubungan antara tema tertentu dengan subsub pokok bahasan yang diambil dari ber-bagai bidang studi terkait. Distribusi frekuensi perolehan skor pembuatan jaringan tema dalam pembelajaran tematik dapat dilihat pada Tabel 6 berikut.

Tabel 6. Distribusi Frekuensi Perolehan Skor Pembuatan Jaringan Tema

\begin{tabular}{ccccc}
\hline No & Interval & Kategori & Frek & $\begin{array}{c}\text { Frekuensi } \\
\text { Relatif } \\
(\boldsymbol{\%})\end{array}$ \\
\hline 1 & $\mathrm{X}<5,25$ & Kurang Sesuai & 0 & 0 \\
2 & $7,5>\mathrm{X} \geq 5,25$ & Cukup Sesuai & 4 & 11,8 \\
3 & $9,75>\mathrm{X} \geq 7,5$ & Sesuai & 9 & 26,5 \\
4 & $\mathrm{X} \geq 9,75$ & Sangat Sesuai & 21 & 61,7 \\
\hline
\end{tabular}

Berdasarkan Tabel 6 dapat dijelaskan bahwa 61,7\% guru SD di Kecamatan Salahutu Kabupaten Maluku Tengah menyatakan membuat jaringan tema dalam pembelajaran tematik termasuk dalam kategori sangat sesuai, $26,5 \%$ termasuk dalam kategori sesuai, 11,8\% termasuk dalam kategori cukup sesuai, dan tidak ada dalam kategori kurang sesuai. Hal ini menunjukan bahwa guru SD di Kecamatan Salahutu Kabupaten Maluku Tengah dalam membuat jaringan tema untuk pembelajaran tematik yang meliputi indikator hakikat jaringan tema, teknik pembuatan jaringan tema, dan kriteria jaringan tema dalam kategori baik yang ditunjukkan oleh persentase terbesar pada frekuensi perolehan skor sangat sesuai berada pada interval angka $61 \%-80 \%$. 


\section{Penyusunan Silabus}

Silabus merupakan garis besar, ringkasan, ikhtisar, atau pokok-pokok isi atau materi pelajaran. Distribusi frekuensi perolehan skor penyusunan silabus pembelajaran tematik dapat dilihat pada Tabel 7 berikut.

Tabel 7. Distribusi Frekuensi Perolehan Skor Pengembangan Silabus

\begin{tabular}{lcccc}
\hline No & Interval & Kategori & Frek $\begin{array}{c}\text { Frekuensi } \\
\text { Relatif } \\
(\%)\end{array}$ \\
\hline 1. & $\mathrm{X}<19,25$ & Kurang Sesuai & 1 & 2,9 \\
2. & $27,5>\mathrm{X} \geq 19,25$ & Cukup Sesuai & 6 & 17,6 \\
3. & $35,75>\mathrm{X} \geq 27,5$ & Sesuai & 6 & 17,6 \\
4. & $\mathrm{X} \geq 35,75$ & Sangat Sesuai & 21 & 61,9 \\
\hline
\end{tabular}

Berdasarkan Tabel 7 dapat dilihat bahwa $61 \%$ guru SD di Kecamatan Salahutu Kabupaten Maluku Tengah menyatakan pengembangan silabus pembelajaran tematik termasuk dalam kategori sangat sesuai, $17,6 \%$ termasuk dalam kategori sesuai, $17,6 \%$ termasuk dalam kategori cukup sesuai, dan 2,9\% dalam kategori kurang sesuai. Hal ini menunjukan bahwa guru SD di Kecamatan Salahutu Kabupaten Maluku Tengah menyusun silabus pembelajaran tematik yang meliputi indikator pengembangan silabus pembelajaran tematik, penetapan SK dan KD, identifikasi materi pokok, perumusan pencapaian indikator kompetensi, pengembangan kegiatan pembelajaran, penentuan jenis penilaian, penentuan alokasi waktu, dan penentuan media/sumber belajar dalam kategori baik yang ditunjukkan oleh persentase terbesar pada frekuensi perolehan skor sangat sesuai berada pada interval angka $61 \%-80 \%$.

\section{Pengembangan RPP}

Rencana Pelaksanaan Pembelajaran (RPP) adalah rencana yang menggambarkan prosedur dan pengorganisasian pembelajaran untuk mencapai satu kompetensi dasar yang ditetapkan dalan standar isi dan telah dijabarkan dalam silabus. Distribusi frekuensi perolehan skor pengembangan rencana pelaksanaan pembelajaran tematik dapat dilihat pada tabel berikut.

Tabel 8. Distribusi Frekuensi Perolehan Skor Pengembangan RPP

\begin{tabular}{ccccc}
\hline No & Interval & Kategori & Frek & $\begin{array}{c}\text { Frekuensi } \\
\text { Relatif }(\%)\end{array}$ \\
\hline 1. & $X<21$ & Kurang Sesuai & 0 & 0 \\
2. & $30>X \geq 21$ & Cukup Sesuai & 1 & 2,9 \\
3. & $39>X \geq 30$ & Sesuai & 11 & 32,4 \\
4. & $X \geq 39$ & Sangat Sesuai & 22 & 64,7 \\
\hline
\end{tabular}

Tabel 8 dapat dilihat bahwa $64,7 \%$ guru di SD Kecamatan Salahutu Kabupaten Maluku Tengah mengembangkan RPP pembelajaran tematik termasuk dalam kategori sangat sesuai, 32\% termasuk dalam kategori sesuai, $29 \%$ termasuk dalam kategori cukup sesuai, dan tidak ada dalam kategori kurang sesuai. Hal ini menunjukan bahwa guru SD di Kecamatan Salahutu Kabupaten Maluku Tengah dalam mengembangkan RPP pembelajaran tematik yang meliputi indikator landasan pengembangan RPP dan komponen RPP dalam kategori baik yang ditunjukkan oleh persentase terbesar pada frekuensi perolehan skor sangat sesuai berada pada interval angka $61 \%-80 \%$.

\section{Pelaksanaan Pembelajaran Tematik}

Pelaksanaan pembelajaran merupakan implementasi dari rencana pelaksanaan pembelajaran. Kemampuan guru dalam melaksanakan pembelajaran tematik masih berada pada kriteria cukup baik. Kategori ini didasarkan pada kemampuan guru yang melaksanakan kegiatan awal, kegiatan inti, dan kegiatan akhir masih berada pada kriteria cukup baik. Distribusi frekuensi perolehan skor pada aspek kemampuan guru dalam pelaksanaan pembelajaran tematik dapat dilihat pada Tabel 9 berikut.

Tabel 9. Distribusi Frekuensi Perolehan Skor Pelaksanaan Pembelajaran

\begin{tabular}{ccccc}
\hline No & Interval & Kategori & Frek & $\begin{array}{c}\text { Frekuensi } \\
\text { Relatif } \\
(\%)\end{array}$ \\
\hline 1 & $\mathrm{X}<5,25$ & Kurang Sesuai & 0 & 0 \\
2 & $7,5>\mathrm{X} \geq 5,25$ & Cukup Sesuai & 8 & 23,5 \\
3 & $9,75>\mathrm{X} \geq 7,5$ & Sesuai & 15 & 44,1 \\
4 & $\mathrm{X} \geq 9,75$ & Sangat Sesuai & 11 & 32,4 \\
\hline
\end{tabular}

Tabel 9 dapat dijelaskan bahwa 32,4\% guru SD di Kecamatan Salahutu Kabupaten Maluku Tengah melaksanakan kegiatan pelaksanaan pembelajaran tematik termasuk dalam kategori sangat sesuai, $44,1 \%$ termasuk dalam kategori sesuai, 23,5\% termasuk dalam kategori cukup sesuai, dan tidak ada dalam kategori kurang sesuai. Hal ini menunjukan bahwa guru di SD Kecamatan Salahutu Kabupaten Maluku Tengah melaksanakan kegiatan pembelajaran tematik yang sesuai meliputi indikator tahap kegiatan awal, tahap kegiatan inti, dan tahap kegiatan akhir dalam kriteria cukup baik yang ditunjukkan oleh persentase terbesar pada frekuensi perolehan skor sesuai berada pada interval angka 41\%-60\%. Untuk menge- 
tahui tingkat kecenderungan masing-masing sub aspek dari pelaksanaan proses pembelajaran tematik dapat dideskripsikan sebagai berikut.

\section{Kegiatan Awal}

Kegiatan awal merupakan persiapan sebelum pembelajaran dimulai untuk menciptakan suasana awal pembelajaran yang efektif, untuk mendorong siswa menfokuskan dirinya agar mampu mengikuti proses pembelajaran dengan baik. Distribusi frekuensi perolehan skor kegiatan awal pembelajaran tematik dapat dilihat pada Tabel 10 berikut.

Tabel 10. Distribusi Frekuensi Perolehan Skor Kegiatan Awal

\begin{tabular}{ccccc}
\hline No & Interval & Kategori & Frek & $\begin{array}{c}\text { Frekuensi } \\
\text { Relatif } \\
(\%)\end{array}$ \\
\hline 1. & $\mathrm{X}<1,75$ & Kurang Sesuai & 0 & 0 \\
2. & $2,5>\mathrm{X} \geq 1,75$ & Cukup Sesuai & 12 & 35,3 \\
3. & $3,25>\mathrm{X} \geq 2,5$ & Sesuai & 15 & 44,1 \\
4. & $\mathrm{X} \geq 3,25$ & Sangat Sesuai & 7 & 20,6 \\
\hline
\end{tabular}

Tabel 10 dapat dijelaskan bahwa 20,6\% guru SD di Kecamatan Salahutu Kabupaten Maluku Tengah pada kegiatan awal pelaksanaan pembelajaran tematik termasuk dalam kategori sangat sesuai, 44,1\% dalam kategori sesuai, 35,3\% dalam kategori cukup sesuai, dan tidak ada dalam kategori kurang sesuai. Hal ini menunjukan bahwa guru SD di Kecamatan Salahutu Kabupaten Maluku Tengah melaksanakan kegiatan awal pembelajaran tematik dalam kategori cukup baik yang ditunjukkan oleh persentase terbesar pada frekuensi perolehan skor sesuai berada pada interval angka $41 \%$ $60 \%$.

\section{Kegiatan Inti}

Kegiatan inti merupakan kegiatan pelaksanaan pembelajaran tematik yang menekankan pada proses pembentukan pengalaman belajar peserta didik. Distribusi frekuensi perolehan skor kegiatan inti pembelajaran tematik dapat dilihat pada tabel berikut.

Tabel 11. Distribusi Frekuensi Perolehan Skor Kegiatan Inti

\begin{tabular}{ccccc}
\hline No & Interval & Kategori & Frek & $\begin{array}{c}\text { Frekuensi } \\
\text { Relatif } \\
(\%)\end{array}$ \\
\hline 1. & $\mathrm{X}<1,75$ & Kurang Sesuai & 1 & 2,9 \\
2. & $2,5>\mathrm{X} \geq 1,75$ & Cukup Sesuai & 11 & 32,4 \\
3. & $3,25>\mathrm{X} \geq 2,5$ & Sesuai & 14 & 41,2 \\
4. & $\mathrm{X} \geq 3,25$ & Sangat Sesuai & 8 & 23,4 \\
\hline
\end{tabular}

Tabel 11 dapat dijelaskan bahwa 23,4\% guru SD di Kecamatan Salahutu Kabupaten Maluku Tengah melaksanakan kegiatan inti pembelajaran tematik termasuk dalam kategori sangat sesuai, 41,2\% dalam kategori sesuai, $32,4 \%$ dalam kategori cukup sesuai, dan 2,9\% dalam kategori kurang sesuai. Hal ini menunjukkan bahwa guru SD di Kecamatan Salahutu Kabupaten Maluku Tengah melaksanakan kegiatan inti pembelajaran tematik dalam kategori cukup baik yang ditunjukkan oleh persentase terbesar pada frekuensi perolehan skor sesuai berada pada interval angka $41 \%-60 \%$.

\section{Kegiatan Akhir}

Kegiatan akhir pembelajaran merupakan kegiatan untuk menutup pembelajaran, yang disertai dengan kegiatan penilaian hasil belajar siswa dan kegiatan tindak lanjut. Distribusi frekuensi perolehan skor dan histogram kegiatan akhir pembelajaran tematik dapat dilihat pada tabel berikut.

Tabel 12. Distribusi Frekuensi Perolehan Skor Kegiatan Akhir

\begin{tabular}{ccccc}
\hline No & Interval & Kategori & Frek & $\begin{array}{c}\text { Frekuensi } \\
\text { Relatif } \\
(\%)\end{array}$ \\
\hline 1. & $X<1,75$ & Kurang Sesuai & 0 & 0 \\
2. & $2,5>X \geq 1,75$ & Cukup Sesuai & 4 & 11,8 \\
3. & $3,25>X \geq 2,5$ & Sesuai & 17 & 50,0 \\
4. & $X \geq 3,25$ & Sangat Sesuai & 13 & 38,2 \\
\hline
\end{tabular}

Tabel 12 dapat dijelaskan bahwa 38,2\% guru SD di Kecamatan Salahutu Kabupaten Maluku Tengah melaksanakan kegiatan akhir pembelajaran tematik termasuk dalam kategori sangat sesuai, 50,0\% termasuk dalam kategori sesuai, $11,8 \%$ termasuk dalam kategori cukup sesuai, dan tidak ada dalam kategori kurang sesuai. Hal ini menunjukan bahwa guru SD di Kecamatan Salahutu Kabupaten Maluku Tengah melaksanakan kegiatan akhir pembelajaran tematik dalam ketegori cukup baik yang ditunjukkan oleh persentase terbesar pada frekuensi perolehan skor sesuai berada pada interval angka $41 \%-60 \%$.

\section{Penilaian Pembelajaran Tematik}

Pelaksanaan penilaian pembelajaran tematik didasarkan pada Peraturan Menteri Pendidikan Nasional No 20 Tahun 2007. Kemampuan guru SD di Kecamatan Salahutu, Kabupaten Maluku Tengah dalam melaksanakan penilaian pembelajaran tematik masih berada pada kriteria cukup baik. Hal ini didasarkan pada guru yang melaksanakan penilaian proses dan 
penilaian hasil pembelajaran tematik dengan cukup baik. Distribusi frekuensi pelaksanaan penilaian pembelajaran tematik dapat dibuat sebagai berikut.

Tabel 13. Distribusi Frekuensi Perolehan Skor Penilaian Pembelajaran

\begin{tabular}{ccccc}
\hline No & Interval & Kategori & Frek $\begin{array}{c}\text { Frekuensi } \\
\text { Relatif } \\
(\%)\end{array}$ \\
\hline 1. & $\mathrm{X}<15,75$ & Kurang Sesuai & 0 & 0 \\
2. & $22,5>\mathrm{X} \geq 5,75$ & Cukup Sesuai & 3 & 8,8 \\
3. & $29,25>\mathrm{X} \geq 22,5$ & Sesuai & 25 & 73,5 \\
4. & $\mathrm{X} \geq 29,25$ & Sangat Sesuai & 6 & 17,7 \\
\hline
\end{tabular}

Tabel 13 dapat dijelaskan bahwa 17,7\% guru SD di Kecamatan Salahutu Kabupaten Maluku Tengah melaksanakan penilaian pembelajaran tematik dalam kategori sangat sesuai, 73,5\% dalam kategori sesuai, 8,8\% termasuk dalam kategori cukup sesuai, dan tidak ada dalam kategori kurang sesuai. Hal ini menunjukan bahwa guru SD di Kecamatan Salahutu Kabupaten Maluku Tengah melaksanakan penilaian pembelajaran yang sesuai meliputi indikator penilaian proses dan penilaian hasil dilaksanakan dengan cukup baik yang ditunjukkan oleh persentase terbesar pada frekuensi perolehan skor berada pada kategori sesuai. Untuk mengetahui tingkat kecenderungan masing-masing sub aspek dari pelaksanaan penilaian pembelajaran tematik dapat di deskripsikan sebagai berikut.

\section{Penilaian Proses Pembelajaran}

Penilaian proses belajar merupakan penilaian yang dilaksanakan pada saat proses pembelajaran sedang berlangsung. Distribusi frekuensi perolehan skor penialaian proses pembelajaran tematik dapat dilihat pada tabel berikut.

Tabel 14. Distribusi Frekuensi Perolehan Skor Penilaian Proses

\begin{tabular}{ccccc}
\hline No & Interval & Kategori & Frek & $\begin{array}{c}\text { Frekuensi } \\
\text { Relatif } \\
(\%)\end{array}$ \\
\hline 1. & $\mathrm{X}<3,5$ & Kurang Sesuai & 1 & 2,9 \\
2. & $5>\mathrm{X} \geq 3,5$ & Cukup Sesuai & 4 & 11,8 \\
3. & $6,5>\mathrm{X} \geq 5$ & Sesuai & 21 & 61,8 \\
4. & $\mathrm{X} \geq 6,5$ & Sangat Sesuai & 8 & 23,5 \\
\hline
\end{tabular}

Tabel 14 dapat dijelaskan bahwa 23,5\% guru SD di Kecamatan Salahutu Kabupaten Maluku Tengah melaksanakan penilaian proses pembelajaran tematik termasuk dalam kategori sangat sesuai, 61,8\% dalam kategori sesuai, $11,8 \%$ dalam kategori cukup sesuai, dan 2,9\% dalam kategori kurang sesuai. Hal ini menun- jukkan bahwa guru SD di Kecamatan Salahutu Kabupaten Maluku Tengah melaksanakan penilaian proses pembelajaran tematik yang meliputi menginformasikan silabus mata pelajaran yang di dalamnya memuat rancangan dan kriteria penilaian pada awal semester dan mengembangkan indikator pencapaian KD dan memilih teknik penilaian yang sesuai pada saat menyusun silabus mata pelajaran dalam kategori cukup baik yang ditunjukkan oleh persentase terbesar pada frekuensi perolehan skor berada pada kategori sesuai

\section{Penilaian Hasil Pembelajaran}

Penilaian hasil pembelajaran dilaksanakan pada akhir pembelajaran, baik berupa evaluasi di kelas, kegiatan tindak lanjut maupun tugas di luar jam pembelajaran. Distribusi frekuensi perolehan skor dan histogram penilain hasil pembelajaran tematik dapat dilihat pada tabel berikut.

Tabel 15. Distribusi Frekuensi Perolehan Skor Penilaian Hasil Pembelajaran

\begin{tabular}{|c|c|c|c|c|}
\hline \multirow[b]{2}{*}{ No } & \multicolumn{4}{|c|}{ Frekuensi } \\
\hline & Interval & Kategori & Frek & $\begin{array}{c}\text { Relatif } \\
(\%)\end{array}$ \\
\hline 1. & $X<12,25$ & Kurang Sesuai & 0 & 0 \\
\hline 2. & $17,5>X \geq 12,25$ & Cukup Sesuai & 4 & 11,8 \\
\hline 3. & $22,75>X \geq 17,5$ & Sesuai & 22 & 64,7 \\
\hline 4. & $X \geq 22,75$ & Sangat Sesuai & 8 & 23,5 \\
\hline
\end{tabular}

Tabel 15 dapat dijelaskan bahwa 23,5\% guru SD di Kecamatan Salahutu Kabupaten Maluku Tengah melaksanakan penilaian hasil pembelajaran tematik termasuk dalam kategori sangat sesuai, $64,7 \%$ dalam kategori sesuai, $11,8 \%$ dalam kategori cukup sesuai, dan tidak ada dalam kategori kurang sesuai. Hal ini menunjukan bahwa guru SD di Kecamatan Salahutu Kabupaten Maluku Tengah melaksanakan penilaian hasil pembelajaran tematik yang meliputi: (1) indikator mengembangkan instrumen dan pedoman penilaian yang sesuai dengan bentuk dan teknik penilaian yang dipilih, (2) melaksanakan tes, pengamatan, penugasan dan/ atau bentuk penilaian lain yang diperlukan, (3) mencatat hasil kemajuan dan kesulitan belajar siswa, (4) mengembalikan hasil pekerjaan siswa yang disertai balikan komentar yang mendidik, (5) memanfaatkan hasil penilaian untuk perbaikan pembelajaran; membuat catatan nilai prestasi belajar siswa disertai deskripsi singkat sebagai cerminan kompetensi utuh, (6) dan membuat catatan hasil penilaian akhlak dan penilaian kepribadian dalam kategori cukup baik yang 
ditunjukkan oleh persentase terbesar pada frekuensi perolehan skor pada kategori sesuai.

\section{Simpulan dan Saran}

Simpulan

Berdasarkan hasil analisis dan pembahasan dapat disimpulkan bahwa (1) kemampuan guru dalam perencanaan pembelajaran tematik di sekolah dasar Kecamatan Salahutu Kabupaten Maluku Tengah termasuk dalam kategori cukup baik. Hal ini didasarkan pada kemampuan guru yang menyatakan pembuatan perencanaan program pembelajaran termasuk cukup baik, kemampuan melakukan pemetaaan standar kompetensi, kompetensi dasar dan indikator termasuk cukup baik, kemampuan membuat jaringan tema termasuk baik, kemampuan penyusunan silabus termasuk baik, dan kemampuan mengembangkan Rencana Pelaksanaan Pembelajaran (RPP) termasuk baik. (2) Pelaksanaan proses pembelajaran termasuk dalam kategori cukup baik. Hal ini didasarkan pada kemampuan guru dalam melaksanakan kegiatan awal dengan cukup baik, kegiatan inti dengan cukup baik, dan kegiatan akhir dengan cukup baik. (3) Penilaian pembelajaran tematik termasuk dalam kategori cukup baik. Hal ini didasarkan pada kemampuan guru yang melaksanakan penilaian proses pembelajaran dengan cukup baik, dan melaksanakan penilaian hasil pembelajaran dengan cukup baik.

Saran

Pemerintah dan pihak sekolah membuka ruang informasi dan memfasilitasi guru untuk mengikuti pendidikan dan pelatihan pembelajaran tematik yang dapat menunjang kompetensi guru di bidangnya masing-masing dan dapat meningkatkan keberhasilan pembelajaran di kelas. Pihak sekolah, dan pengawas satuan pendidikan menertibkan guru yang belum menyusun dan mengembangkan silabus dan RPP, karena komponen tersebut sangat penting sebagai modal guru melaksanakan pembelajaran.

\section{Daftar Pustaka}

Chiappetta, E.L. \& Koballa, T.R. (2010). Science instruction in the midlle and secondary schools. Boston: Allyn \& Bacon.
Collins, Gillian \& Dixon, Hazel. (1991). Integrate learning planned curriculum units. Australia: Bookshelf Tt.

Depdiknas. (2002). Undang-undang Republik Indonesia Nomor 23 Tahun 2002 tentang Perlindungan anak

(2003). Undang-undang Republik Indonesia No 20 Tahun 2003 tentang Sistim Pendidikan Nasional.

(2006). Peraturan Menteri Pendidikan Nasional Republik Indonesia Nomor 22 Tahun 2006 tentang standar isi untuk satuan pendidikan dasar dan menengah..

Fogarty, R. (1991). The mindful school: How to integrate the curricula. Palatine: IRI/Skylight publishing, Inc.

Hermawan, Asep Herry, dkk. (2007). Belajar dan pembelajaran SD. Bandung: UPI Press.

Hudson, D. (2009). Good teacher, good schools: How to create a successful school. New York: Routledge.

Loughran, Sandra B. (2005). Thematic Teaching in Action. Kappa Delta Pi Record; 41, 3; ProQuest Education Journals pg. 112. Diambil pada tanggal 26 Desember 2012, dari http://search.proquest.com/docview/232030807/13BE4C3 F9A17498971D/1?accountid=31324

Martin, et al. (2005). Teaching science for all children: inquiry methods for constructing understanding. Boston: Pearson.

Trianto. (2009). Mengembangkan model pembelajaran tematik. Jakarta: Prestasi Pustaka Publisher.

(2010). Mendesain model pembelajaran inovatif-progresif: konsep, landasan dan implementasinya pada kurikulum tingkat satuan pendidikan (KTSP). Jakarta: Kencana.

(2011). Desain pengembangan pembelajaran tematik bagi anak usia dini TK/RA \& Anak kelas awal SD/MI. Jakarta: Kencana.

Wina, S. (2011). Strategi pembelajaran berorientasi standar proses pendidikan. Jakarta: Kencana 